\title{
Study on Cultivation of Sports Brokers in China
}

\author{
Yue Wenyan
}

(Jinan University, Guangzhou 510632)

\author{
Key words: Sports brokers, Cultivation
}

\begin{abstract}
Sports brokerage industry is not only the crucial part of sports industry but the "lubricant" and "booster" for guaranty of healthy, ordered and rapid-developing sports industry. It has the connecting role in sports chain. However, our brokerage industry market is short of excellent talents. What's more, brokerage activity is still in infant stage, which can not compete with foreign sports brokerage companies. Hence, it is urgent to enhance the cultivation of sports brokers from the strategic aspect of sports industry development.
\end{abstract}

\section{Introduction}

Foreign countries have cultivated sports brokers as the senior talents. On the contrary, our country develops it late so long-term professional talent cultivation system has not yet formed due to the short-term pre-job training with little content which leads to be eager for quick success and instant benefit with high passing rate and low failure rate. Sports brokerage activities are related to many fields of professional knowledge like sports, economy, law, advertising, marketing and public relation so the excellent operators should have a good command of comprehensive knowledge structure or have the knowledgeable consultant around. That is why Chinese brokerage activity is still in infant stage, which can not compete with foreign sports brokerage companies.

\section{Current state of cultivation of sports brokers in China}

At present, our country's sports brokers are from all walks of class and at all ages, focusing on youths with university background. Most sports brokers are sports workers, teachers and managers. The sports brokers team is becoming young, educated and diverse. They have an increasing influence on society. The sports brokers have high degree but low quality owing lack of systematical study and practice. As for sports workers, although they possess professional knowledge but lack operation knowledge. People from other industries are short of professional knowledge. Both of them are in absence of knowledge in law and marketing. It is urgent for them to renew their improper and old knowledge structure and receive training. Beijing Sport University has offer sports brokerage major. Some scholars, like Ma Tie, Zhang Li, Huang Wenhui, devoted to sports brokerage research hold that our countries' sport colleges and universities should have their eyes on talents' knowledge structure and ability formation, adjust specialty and major arrangement and increase sports brokerage major offer in terms of sports development requirement under market economy. Meanwhile, they advocate multi-channel and multi-level sports brokers cultivation system. Luo Ping consider that the establishment of sports brokers system is close to cultivation of sports brokers. Therefore, it is crucial to enhance cultivation of sports brokers.

\section{Thinking over enhancing cultivation of sports brokers}

Promoting strategic research and formulating talent plan

Compared to sport in the $20^{\text {th }}$ century, the $21^{\text {st }}$-century sport in our country is featured by that sport will be the emerging impetus to promote Chinese economy development. Since success of entry of WTO and Olympic Games Bidding, sports industry faces rapid-development opportunity, which raises higher demand of domestic sports brokers. With 2008 Olympic Games approaching, it greatly needs talents who are skilled at large match operation and sports industry development. Aiming at great need of sports management talents, our country issued the National Program for 
Sport Reform and Development During 2001 2010, which puts forward to highlight sports industry construction, train the existing sports management staffs, introduce high-level managers, enrich sports industry system, enhance sports industry organization and management skill and research on current state of sports economy and forecasting and encourage the qualified universities and colleges to offer majors related to sports economy. Talent is the foundation of a nation; it's the management of politics, and the prosperity of business. To put talents planning into general planning of sports industry development is the important guaranty to realize the strategic goal of sports industry. For the general development goal, the systematical talent strategy must be implemented, not only to conduct systematical plan of the guiding principle, general goal, focal point of the work and measure of talent strategy but to systematically plan the objective planning, hierarchical structure, development pattern and quality requirement of talent resources.

Enhancing legal system development construction and implementing institutionalized management.

The short-term train serves as the supplement and renewal of official university and college cultivation. It can help the sports brokers to adjust knowledge structure and renew their knowledge.

Mr. Zhang Bolin, minister of Ministry of Human Resources and deputy charge-man of central government talent coordination team, puts out that "set up the concept of education, train and innovate further education management system". The author has visited some scholars and experts who have take part in sports brokers train class. They hold that management system, strict laws and regulations and fair competitive rules on sports brokers are the basis for healthy development of sports brokerage industry. No. 1 factor of influencing our sports brokerage industry development is lack of market rule. The reasons are: firstly, as the newly-emerging industry, if the sports brokerage industry is short of practical and effective management systems as guaranty in the beginning, industry specification development can not be guaranteed. Once the problems occur, they can not be solved timely and leave the threat for its further healthy development; secondly, it lacks industry self-discipline so the sports brokers become loose and get information blocked, which can not realize resource share and form competition situation and do no good to whole development of sports brokerage industry. Some illegal sports brokers shuttle back and forth in the clubs, occupying parts of market, which is harmful to interests of legal brokers. The perfect management rules and regulations must be formulated and management of General Administration of Sport and Administration for Industry and Commerce should be cleared in order to standardize sports brokerage market, enhance development of domestic sports brokers, mobilize talents' enthusiasm, create a sound, legal and fair environment for brokerage activity and sports brokers, sustain the interest of trustors and the third party, establish energetic sports mechanism and sound operation mechanism and push forward industrialization and professionalization development of our country's sport industry.

Establishing train base and improving train system

It is shown that the shortage of professional talents is one of main factors to influence development of our sports brokerage industry. According to professional characteristics of sports brokers, the following professional quality is needed: firstly, being knowledgeable, secondly, having strong ability. Concretely, staffs who are engaged in sports brokerage should have possess the following quality: proper knowledge structure; strong sense of information and judgement of market opportunity; law sense; honesty; good public relation ability; sound psychological quality. The knowledge reservation and professional quality of sports brokers have a direct influence on service quality of sports brokerage as well as the development speed and quality of the industry. It is meaningful to increase the professional quality of sports brokers. On the one hand, it depends in personal practice. On the other hand, it also depends on efficient train channels. In the survey, it can be seen that many experts and scholars think it is necessary to establish train system for our country's sports brokers. Hence, our country should set up scaled sports brokers train base and make pre-job train, annual train and special talent train of sports brokers systematical. Depending on the need, primary, secondary and senior train class should be provided in order to improve the professional quality of the industry.

Discussing train disciplines and guaranteeing train quality 


\section{A.Establishing the cultivation goal system of sports brokers}

The demand for high-quality sports brokers talents makes the cultivation of sports brokers at high point and high standard level. The cultivation goal of sports brokerage major is to train compound talents who can take part in sports brokerage activity. The complexity of sports brokerage activity determines the diversity of sports brokers' knowledge structure. Under the specific historical condition, the reappearing quality, endocentric quality and single quality of the talent formation are not fit for the global fierce competition after entry of WTO. The sports brokerage is faced with domestic and international competition challenge. The mono-knowledge structure and skill structure can not meet the demand of market. The nature of market economy: competition and benefit, fundamentally requires talents' knowledge structure and skill structure to be compound. Under the background of entry of WTO, our talent resource team quality needs overall improvement and transformation from three strategic aspects: transformation from reappearing quality to innovation quality, from endocentric quality to exocentric and international-orientated quality, from single quality to compound quality. Sports brokers should not only extend their unitary knowledge and skill but apply to multi-knowledge and skill. The compound talents are needed in sport industry.

B. Focusing on cultivation of innovative talents

Each commercial development of sport, expansion of performance market, development of sports team or sportsman's intangible assets and commercial operation related to sports reflect innovation of sports brokers. For example, world-known sports brokers like: English boxing brokers, Warren , American basketball brokers, Falck and boxing brokers, Don King are innovative in the brokerage activity so they become prominent. Therefore, emphasis should exerted on train and development of innovative talents. The innovative quality can be reflected: firstly, strong sense of innovation, it is the active and productive ideology in human awareness activity and also the premise and impetus of creative activity. The sense of innovation is made up of innovative interest, hobby, activeness and correct innovative intention; secondly, outstanding creativity which includes creative thinking ability and practice ability. Relatively, creative thinking is the premise and its nature is the combination of "choice, breakthrough and restructuring". In the basic forms of creative thinking, divergent thinking should be emphasized because its basic function is difference-seeking and innovation; thirdly, distinct creative personality, that is the active psychological quality for the subject to gain success including be enterprising, aggressive, confident, brave, tough and independent.

C.Vigorously developing international-orientated talents

It is the regulation of globalization of economic development. Since China's entry of WTO, inter-national brokerage activities are increasing. Our country's sports brokers should not only recapture the domestic market occupied by foreign brokerage company but take an active part in striving for foreign market. Without international-orientated talents, it is hard to achieve this goal. The international-orientated talents are featured by: firstly, having extensive global version and strong sense of innovation and putting the version and sense on the patriotism; secondly, mastering professional international knowledge and being good at integrate it with local culture; thirdly, having an intimate knowledge of international practices related to sports brokerage activities; fourthly, having strong intercultural communication ability and good command of English;

Displaying advantages of higher institutes and systematically cultivating high-quality sports brokers

Sports brokers knowledge structure includes : (1) Professional sports knowledge, including getting familiar with the general rules of sports and the development trend of a certain project, analyzing sports market, being familiar with relative sports organization and its laws. (2) Law knowledge, including the state issued relevant basic rules and regulations and related laws and regulations of the sports field. (3) Professional economic knowledge, including economics, market economy theory, market marketing, sponsorship theory. Training is not equal to educating; training class can't bear the important task of cultivating sports brokers. Most experts and students have chosen the professional training in higher education institution, which is because of university cultivating talents and its unique educating advantage. Experts believe that the main advantage for higher education institution setting up sports brokers major is the good study environment. The higher education institution has good learning atmosphere, beautiful and comfortable study 
environment, abundant of library resources, which have provide favorable conditions for students. What's more, they have rich teachers' resources. Based on specialized personnel market demand, they formulate talents training target and specification, work out teaching plan, clear curriculum system, train teachers to teach students in a planned way, mainly to cultivate students' ability, finally realize educational target and meet needs of society. Professional training in higher education institution follows students' cognitive way. Considering the special requirements of professional sports brokers, it is suitable for the sports colleges and schools and other universities jointly organized, or by the comprehensive university sports colleges and financial management departments jointly organized.

\section{References}

[1] Bao Mingxiao. Sport Industry, [M] Beijing: People's Sports Publishing House of China, 2000.

[2] Editors: TAN Jianxiang, Ma Tie, General Guide of Sport Brokerage, [M] Beijing: Higher education press, 2004

[3] Zhang Xianjun, Cultivation Policy of Sports brokers, [J] Zhejiang Sport Science, 2000（2） 